\title{
THE EFFECT OF NITROGEN AND SULPHUR FERTILIZATION ON YIELD AND QUALITY OF KOHLRABI (Brassica oleracea, L. $)^{(1)}$
}

\author{
Tomáš Lošák ${ }^{(2)}$, Jaroslav Hlušek ${ }^{(3)}$, Stanislav Kráěmar ${ }^{(4)}$ \\ \& Ladislav Varga ${ }^{(5)}$
}

\begin{abstract}
SUMMARY
In a greenhouse pot experiment with kohlrabi, variety Luna, we explored the joint effect of $\mathrm{N}(0.6 \mathrm{~g} \mathrm{~N}$ per pot $=6 \mathrm{~kg}$ of soil $)$ and $S$ in the soil $\left(25-35-45 \mathrm{mg} \mathrm{kg}^{-1}\right.$ of $\mathrm{S})$ on yields, on $\mathrm{N}, \mathrm{S}$ and $\mathrm{NO}_{3}{ }^{-}$content in tubers and leaves, and on alterations in the amino acids concentration in the tubers. $S$ fertilisation had no effect on tuber yields. The ranges of $\mathrm{N}$ content in tubers and leaves were narrow (between 1.42$1.48 \% \mathrm{~N}$ and $1.21-1.35 \% \mathrm{~N}$, respectively) and the effect of $\mathrm{S}$ fertilisation was insignificant. $\mathrm{S}$ concentration in the tubers ranged between 0.59 and $0.64 \% \mathrm{~S}$. $\mathrm{S}$ fertilisation had a more pronounced effect on the $\mathrm{S}$ concentration in leaf tissues where it increased from 0.50 to 0.58 or to $0.76 \% \mathrm{~S}$ under the applied dose. The $\mathrm{NO}_{3}$ content was higher in tubers than in leaves. Increasing the $\mathrm{S}$ level in the soil significantly reduced $\mathrm{NO}_{3}$ - concentrations in the tubers by $42.2-53.6 \%$ and in the leaves by $8.8-21.7 \%$. Increasing the $\mathrm{S}$ content in the soil reduced the concentration of cysteine + methionine by $16-28 \%$. The values of valine, tyrosine, aspartic acid and serine were constant. In the $S_{0}, S_{1}$, and $S_{2}$ treatments the levels of threonine, isoleucine, leucine, arginine, the sum of essential amino acids and alanine decreased from 37 to $9 \%$. The histidine concentration increased with increasing $S$ fertilisation. $\mathrm{S}$ fertilisation of kohlrabi can be recommended to stabilize the yield and reduce the undesirable $\mathrm{NO}_{3}$ - contained in the parts used for consumption.
\end{abstract}

Index terms: ammonium sulphate, dose, tuber, leaves, nitrates, amino acid concentrations.

\footnotetext{
(1) Received for publication in june of 2007 and approved in november of 2007.

(2) Assistente do Professor, Instituição da química agrária, perícia dos solos, microbiologia e alimentação das plantas, Universidade de Mendel de Agricultura e Silvicultura em Brno, Zemědělská 1, 61300 - Brno - República Checa (CZ). E-mail: losak@mendelu.cz

(3) Professor, Instituição da química agrária, perícia dos solos, microbiologia e alimentação das plantas, Universidade de Mendel de Agricultura e Silvicultura em Brno, Zemědělská 1, 61300 - Brno - República Checa (CZ). E-mail: hlusek@mendelu.cz

(4) Professor, Instituição da engenharia de alimentação, Universidade de Tomáš Bată em Zlín, Námìstí T.G. Masaryka 275, 76272 - Zlín - República Checa (CZ). E-mail: kracmar@ft.utb.cz

(5) Assistente do Professor, Instituição da química agrária e alimentação das plantas, Universidade Eslovaca de Agricultura em Nitra, Tr. A. Hlinku 2, 94976 - Nitra - República Eslovaca (SK). E-mail: Ladislav.Varga@uniag.sk
} 


\title{
RESUMO: EFEITO DA ADUBAGEM COM O NITROGÉNIO E ENXOFRE AO RÉDITO E À QUALIDADE DAS COUVES-RÁBANOS (Brassica oleracea,
} L.)

\begin{abstract}
Deficiência aguda de $S$ no solo tem sido observada na Europa desde os anos 1980. $O$ couve-rábano é uma das plantas com maior exigência nesse nutriente e sua interação com o $N$ é frequentemente relatada na literatura. Este trabalho foi conduzido em casa de vegetação visando testar o efeito da aplicação de $S$, na presença de $N$, na produção e qualidade de couve-rábano (Brassica oleracea, L., variedade Lua). As plantas foram cultivadas em vasos contendo $6 \mathrm{~kg}$ de solo, aos quais foram aplicados $0,6 \mathrm{~kg}$ de $N$ e $S$ para se obter os teores no solo de: 25 (teor natural), 35, ou $45 \mathrm{mg} \mathrm{kg}^{-1}$. Foram avaliadas a produção e o teor de $\mathrm{N}, \mathrm{S}$ e $\mathrm{NO}_{3}$ - nas raízes e nas folhas e as alterações no teor de aminoácidos nas raízes. A produção de raízes do couve-rábano não afetada pela adubação com $S$. O teor de $N$ nas raízes e nas folhas variou de 1,42-1,48 \% e de 1,21-1,35\% de $N$, respectivamente, não sofrendo efeito significativo da adubação com $S$. $O$ teor de $S$ nas raízes oscilou entre 0,59-0,64 \% de S. A aplicação de $S$ influenciou positivamente o seu teor no tecido foliar, que apresentou estreita relação com os teores do nutriente no solo, chegando a 0,50;0,58 e a $0,76 \%$ de $S$, respectivamente, para os três teores testados. O teor de $\mathrm{NO}_{3}$ - foi maior nas raízes do que nas folhas. $O$ aumento das doses de $\mathrm{S}$ reduziu o teor de $\mathrm{NO}_{3}$ nas raízes, em 42,2 a 53,6 \%, e nas folhas em 8,8 a 21,7\%. O aumento do teor de $S$ no solo reduziu o teor de cisteína + metionina em valores que variaram de 16 a $28 \%$, mas não afetou os teores de valina, tirosina, ácido aspártico e serina. Com a variação dos teores de $S$ entre 25 e $45 \mathrm{mg} \mathrm{kg}$, houve decréscimo de treonina, isoleucina, leucina, arginina, e a soma de amino ácidos esenciais e alanina na faixa de 37 a $9 \%$. O teor de histidina aumentou com a elevação do teor de $S$ no solo. A adubação do couve-rábano com $S$ é recomendada sobre tudo para a estabilização da produção e para a redução dos teores de $\mathrm{NO}_{3}$, cuja presença em alimentos é indesejada.
\end{abstract}

Termos de indexação: sulfato de amônio, dose, raízes, folhas; nitrato; aminoácidos.

\section{INTRODUCTION}

An acute deficiency of sulphur (S) in the soil has been observed in Europe since the 1980ies. In the Czech Republic this phenomenon was intensified after 1990. Vegetables requiring a higher supply of S began to respond very sensitively. One of the most demanding vegetables is kohlrabi, which absorbs $1.5 \mathrm{~kg} \mathrm{~S}$ per ton yield. It is the most $\mathrm{S}$-dependent of all brassicas. The typical visual $\mathrm{S}$ deficiency symptom in kohlrabi is inhibited leaf formation and a light colour of the youngest leaves. The reduced soil content of available $\mathrm{S}$ is the result of reduced applications of mineral and organic fertilisers and fungicides (Hlušek et al., 2003).

The substantial decrease in $\mathrm{SO}_{2}$ emission to less than $10 \mathrm{~kg} \mathrm{ha}^{-1}$ of S further intensified S deficiency in plants, because as much as $30 \%$ of its total amount can be absorbed from $\mathrm{SO}_{2}$ in the air. The $\mathrm{S}$ cycle and its effect on plants are often compared to $\mathrm{N}$ (oxidation in soil and reduction in plants). The main difference is that $\mathrm{S}$ from organic compounds can be re-oxidised to $\mathrm{SO}_{4}-\mathrm{S}$ in plants (Vanik et al., 2001).

Much like N, S is highly mobile in the soil with a limited sorption capacity. Plants take it up from the soil solution mainly in the form of sulphates $\left(\mathrm{SO}_{4}{ }^{2-}\right)$
(Marschner, 1995). After reduction in the plant S participates in various primary and secondary compounds, such as the amino acids cysteine and methionine, vitamins $\mathrm{B}_{1}$ and $\mathrm{H}$ and enzymes and coenzymes (Haneklaus et al., 1997). Other Scontaining compounds are, e.g., tripeptide glutathione (antioxidant and precursor of phytochelatins, which are able to influence the detoxification of some heavy metals), ferredoxine, sulpho-lipids, glucosinolates and others (Schubert, 2002).

One of the essential amino acids, Methionine $\left(\mathrm{C}_{5} \mathrm{H}_{11} \mathrm{O}_{2} \mathrm{NS}\right)$ is, together with cysteine $\left(\mathrm{C}_{3} \mathrm{H}_{7} \mathrm{O}_{2} \mathrm{NS}\right)$, an indispensable component of proteins - their bonds play an important role in the protein structure where they often form intra or inter-chain disulphide bridges. The $\mathrm{S}$ content in proteins is relatively stable and in a certain proportion to $\mathrm{N}$ (Vaněk et al., 2001).

The balance of all macro and micro biogenic elements in the soil is crucial when growing kohlrabi, particularly in the case of $\mathrm{N}$, which determines the yield level as well as the $\mathrm{NO}_{3}$ - content. The production of one ton of kohlrabi draws $5 \mathrm{~kg} \mathrm{~N}$. In terms of its use and losses it would be suitable to split the total amount of $\mathrm{N}$ in mineral fertilisers in doses and apply it in the soil prior to sowing (Hlušek et al., 2002). Schenk et al. (1991) reported that for kohlrabi the 
content of mineral $\mathrm{N}$ should be contained in the $0-0.3 \mathrm{~m}$ layer. The use of fertiliser $\mathrm{N}$ is inhibited in $\mathrm{S}$ deficit crops. This could increase the escape of $\mathrm{N}$ into the environment, particularly by $\mathrm{NO}_{3}{ }^{-}$leaching into the hydrosphere or via gas losses into the atmosphere. Every missing kilogram of $\mathrm{S}$, which limits plant growth, causes N losses of 4-15 kg (Schnug, 1991). Under $\mathrm{S}$ deficiency higher $\mathrm{N}$ doses increase the deficiency (Janzen \& Bettany 1984), resulting in further yield reduction.

The nitrate $\left(\mathrm{NO}_{3}{ }^{-}\right)$concentration in vegetables is an important quality criterion (Schuphan, 1976; Vetter, 1988). In plant chloroplasts $\mathrm{S}$ is a component of the enzyme nitrite reductase which is responsible for the reduction of $\mathrm{NO}_{2}^{-}$to $\mathrm{NH}_{3}$ (Mengel \& Kirkby, 1978). Paulsen (2001) pointed out the risk of increased levels of non-protein $\mathrm{N}$ in plants. Under $\mathrm{S}$ deficiency, the $\mathrm{NO}_{3}^{-}$content can increase and after reduction to $\mathrm{NO}_{2}{ }^{-}$, block the ability of haemoglobin to transfer oxygen, or form the first degree of carcinogenic nitrosamines. Schnug (1990) also stated that the $\mathrm{NO}_{3}$. content in vegetable tissues increased under acute $\mathrm{S}$ deficiency.

The objective of the greenhouse pot experiment with kohlrabi was to test the effect of joint $\mathrm{N}$ and $\mathrm{S}$ fertilisation on kohlrabi yields, $\mathrm{NO}_{3}{ }^{-}$content in tubers and leaves, and changes in the amino acid concentrations.

\section{MATERIALS AND METHODS}

The greenhouse pot experiment with kohlrabi was established on 24 March 2005 in the greenhouse of the Department of Agrochemistry, Soil Science, Microbiology and Plant Nutrition at the Mendel University of Agriculture and Forestry in Brno. Mitscherlich pots were filled with $6 \mathrm{~kg}$ soil (45\% clay) characterised as fluvial soil. The agrochemical properties are given in Table 1.

The soil was analyzed for $\mathrm{CH}_{3} \mathrm{COOH}, \mathrm{NH}_{4} \mathrm{NO}_{3}$, $\mathrm{NH}_{4} \mathrm{~F}, \mathrm{HNO}_{3}$ and EDTA by Mehlich III extraction (Mehlich, 1984). Colorimetry was used to determine the content of available $\mathrm{P}$ in the extract and atomic absorption spectrophotometry (AAS) to determine available $\mathrm{K}, \mathrm{Mg}$ and $\mathrm{Ca}$. The micronutrients $\mathrm{Zn}$ and Fe were extracted using the Lindsay-Norwell procedure (Richter et al., 1999) and the AAS method was used for their determination. Extraction with de-mineralised water at a ratio of $1: 5$ for $16 \mathrm{~h}$ on a rotation shaker preceded the determination of $\mathrm{SO}_{4}-\mathrm{S}$ in the soil. For the actual measurements we used capillary zone electrophoresis (CZE) with silica capillary. The activity of hydrogen ions was detected in a $\mathrm{CaCl}_{2}\left(c=0.01 \mathrm{~mol} \mathrm{dm}^{-3}\right)$ soil extract by a potentiometer with a glass electrode against a reference electrode. The soil showed alkali soil reaction $(\mathrm{pH})$ and the content of available $\mathrm{P}$ was high. The $\mathrm{K}$, Ca, $\mathrm{Mg}, \mathrm{Zn}$, and Fe levels represented a good nutrient level.

The experiment involved three treatments, all of which were fertilised at the same level $(0.6 \mathrm{~g} \mathrm{~N}$ per pot) in the form of ammonium nitrate $(34.5 \% \mathrm{~N})$. Table 2 shows the experimental treatments. Treatment $1\left(\mathrm{~S}_{0}\right)$ was not fertilised with $\mathrm{S}$ (natural content in the soil-25 mg kg-1 of $\mathrm{SO}_{4}-\mathrm{S}$ ). In treatments $2\left(\mathrm{~S}_{1}\right)$ and $3\left(\mathrm{~S}_{2}\right)$ the $\mathrm{SO}_{4}-\mathrm{S}$ in the soil was increased to the required level (35 and $45 \mathrm{mg} \mathrm{kg}^{-1}$ of $\mathrm{SO}_{4}-\mathrm{S}$, respectively) by applying ammonium sulphate (20.5\% $\mathrm{N}$ and $24 \% \mathrm{~S}$, respectively). This is the most widespread nitrogen-mineral fertiliser with a physiological acid reaction, which is particularly suitable for neutral to alkali soils.

Kohlrabi variety Luna was sown in pots on 29 March 2005. Fertilisers were applied via irrigation solution on 9 May 2005, after previous thinning to 3 plants per pot at the 4-leaf stage. The experiment involved 3 treatments, each of which was repeated 4 times. Plants were regularly irrigated with demineralised water during the growing season to $60 \%$ of the maximal capillary capacity. The pots were monitored for water content every day. The top soil layer $(0.02 \mathrm{~m})$ was loosened with a special garden fork five times, together with weeding. Plants were protected against aphids (Aphis) with Pirimor (0.05\%).

\section{Table 2. Experimental treatments}

$\mathrm{N}^{\mathrm{o}}$ Treatment $\mathrm{N}$ dose Content of $\mathrm{SO}_{4}-\mathrm{S}$

\begin{tabular}{cccc}
\hline & & g/pot & $\mathrm{mg} \mathrm{kg}^{-1}$ \\
1 & $\mathrm{~S}_{0}$ & 0.6 & 25 \\
2 & $\mathrm{~S}_{1}$ & 0.6 & 35 \\
3 & $\mathrm{~S}_{2}$ & 0.6 & 45 \\
\hline
\end{tabular}

Table 1. Agrochemical characteristic of the soil

\begin{tabular}{|c|c|c|c|c|c|c|c|}
\hline $\mathrm{pH} / \mathrm{CaCl}_{2}$ & $\mathbf{P}$ & $\mathbf{K}$ & $\mathrm{Ca}$ & Mg & $\mathrm{SO}_{4}-\mathrm{S}$ & $\mathrm{Zn}$ & $\mathrm{Fe}$ \\
\hline & \multicolumn{4}{|c|}{$-\mathrm{mg} \mathrm{kg}^{-1}($ Mehlich-3) } & \multicolumn{3}{|c|}{$\mathrm{mg} \mathrm{kg}^{-1}$} \\
\hline 7.5 & 138 & 226 & 2.784 & 167 & 25 & 2.4 & 42 \\
\hline
\end{tabular}


The tubers were harvested at full maturity on 27 June 2005. Immediately after harvest the individual tubers without leaves were weighed. Nitrate concentration ( $\mathrm{mg} \mathrm{kg}^{-1}$ of $\mathrm{NO}_{3}^{-}$) was determined in the fresh matter tubers and leaves by a potentiometer using ion selective electrode (ISE). The raw tubers were chopped, then lyophilised and homogenised in a fragmentation mill. The methods for laboratory feeds testing of were applied according to regulations of the Ministry of Agriculture of the Czech Republic (Ministerstvo, 2001).

Samples for amino acid determination were adjusted using acidic and oxidative acidic hydrolysis $\mathrm{HCl}\left(\mathrm{c}=6 \mathrm{~mol} \mathrm{dm}^{-3}\right)$. The chromatographic analysis of sample hydrolysates was performed in the analyzer AAA 400 (manufacturer INGOS Prague, CR) and using Na-citrate buffers and ninhydrin detection (Official Journal..., 1978; Kráěmar et al., 1998).

All results were evaluated using the analysis of variance (ANOVA). Correlation matrices and regression functions were calculated according to Snedecor \& Cochran (1967) by the statistical software package Unistat, v.5.1 - UNISTAT® Limited, London, England (Minařík \& Hofbauer, 2003).

\section{RESULTS AND DISCUSSION}

A typical characteristic of kohlrabi is the high withdrawal of $\mathrm{N}$ from the soil (Feller \& Fink, 1997) and any $\mathrm{NO}_{3}-\mathrm{N}$ deficiency in the soil reduces yields (Steingrobe \& Schenk, 1991). Sharof \& Weir (1994) studied the minimum amount of $\mathrm{N}$ required for vegetable crops including kohlrabi in relation to components of $\mathrm{N}$ balance in the soil and calculated that $\mathrm{N}$ requirement values were invariably lower than $\mathrm{N}$ soil levels. Results of yields are listed in table 3.

The tuber weight in fresh matter was not significantly affected by S application with a slight variation between 106.8 and $108.5 \mathrm{~g}$ (Table 3). Nevertheless Prášková (2006) reported that in a pot experiment with kohlrabi the yields increased from 2.7 to $8.5 \%$ under $\mathrm{S}$ doses increasing from $13.7-$ 20-40 mg kg-1. Likewise, Hlušek et al. (2003) stated that kohlrabi tuber yields increased by $10.5 \%$ when the $\mathrm{S}$ soil content increased from 13.7 to $40 \mathrm{ppm}$ and the $\mathrm{N}$ level was $0.75 \mathrm{~g} \mathrm{~N}$ per pot. Contrastingly, Sanderson \& Carter (2002) discovered that yields of brassicas were not stimulated by S application.

The $\mathrm{NO}_{3}{ }^{-}$concentration in plants is affected primarily by the vegetable species, level of $\mathrm{N}$ fertilisation, the respective plant organ, growth stage and $\mathrm{S}$ concentration in the tissues. A negative linear correlation was discovered between $\mathrm{NO}_{3}{ }^{-}$in the tissues and the S concentration in plants (Schnug, 1990). Our results proved that the $\mathrm{NO}_{3}^{-}$content was highest in the control treatment without $\mathrm{S}$ fertilisation, both in tubers and leaves (Table 3). More $\mathrm{NO}_{3}{ }^{-}$was stored in the tubers than in leaves and with an increasing soil $\mathrm{S}$ level the concentrations dropped significantly by $53.6 \%$ in the tubers and by $21.7 \%$ in the leaves (Treatment $\mathrm{S}_{1}$ ). Together with an increasing dose of $\mathrm{S}$ the tuber/leaf ratio in the $\mathrm{NO}_{3}{ }^{-}$content narrowed down from 1.76 (Treatment $\mathrm{S}_{0}$ ) to 1.12 (Treatment $\mathrm{S}_{2}$ ). In a kohlrabi experiment Hlušek et al. (2003) also discovered that the $\mathrm{NO}_{3}^{-}$content in tubers decreased by $14.2 \%$ at a level of $40 \mathrm{ppm} \mathrm{S}$ in the soil and $0.75 \mathrm{~g}$ N per pot. Lošák (2005) reported a drop in $\mathrm{NO}_{3}$ - contents in onion by $13.1 \%$ related with an increase in the $\mathrm{SO}_{4}-\mathrm{S}$ level in the soil to $40 \mathrm{ppm}$.

The $\mathrm{S}$ doses did not affect the $\mathrm{N}$ concentration in kohlrabi tubers, which varied in a narrow range between 1.42 and $1.48 \% \mathrm{~N}$ (Table 4). For the S contents the differences among treatments were not significant either $(0.59-0.64 \% \mathrm{~S})$ and the N/S ratio was also narrow, i.e. 2.22-2.50. In contrast, Smatanová et al. (2004) reported in increase in the S content in peppers from $0.08 \% \mathrm{~S}$ to $0.24 \% \mathrm{~S}$ associated with an increased $\mathrm{S}$ content in the soil from 7.8 to $30.6 \mathrm{ppm}$.

Table 4. Chemical analyses of kohlrabi tuber (\% in dry matter)

\begin{tabular}{cccc}
\hline Treatment & $\% \mathbf{N}$ & $\% \mathbf{S}$ & $\mathbf{N} / \mathbf{S}$ \\
\hline $\mathrm{S}_{0}$ & 1.45 & 0.59 & 2.46 \\
$\mathrm{~S}_{1}$ & 1.42 & 0.64 & 2.22 \\
$\mathrm{~S}_{2}$ & 1.48 & 0.59 & 2.50 \\
\hline
\end{tabular}

Table 3. Yield results of kohlrabi experiment

\begin{tabular}{|c|c|c|c|c|c|c|c|}
\hline \multirow[t]{2}{*}{ Treatment } & \multicolumn{2}{|c|}{$\begin{array}{c}\text { Weight of } 1 \text { tuber without } \\
\text { leaves }(n=12)\end{array}$} & \multicolumn{2}{|c|}{$\begin{array}{l}\mathrm{NO}_{3}^{-} \text {in tuber } \\
\quad(n=12)\end{array}$} & \multicolumn{2}{|c|}{$\begin{array}{c}\mathrm{NO}_{3}-\text { in leaves } \\
(n=12)\end{array}$} & \multirow[t]{2}{*}{$\begin{array}{l}\text { Ratio } \mathrm{NO}_{3}^{-} \\
\text {tuber/leaf }\end{array}$} \\
\hline & $\mathrm{g}$ & rel. $\%$ & Ppm & rel. $\%$ & Ppm & rel. $\%$ & \\
\hline $\mathrm{S}_{0}$ & $108.5^{\mathrm{a}}$ & 100 & $46.5^{\mathrm{a}}$ & 100 & $26.3^{\mathrm{a}}$ & 100 & 1.76 \\
\hline $\mathrm{S}_{1}$ & $106.8^{a}$ & 98.4 & $21.6^{b}$ & 46.4 & $20.6^{b}$ & 78.3 & 1.05 \\
\hline $\mathrm{S}_{2}$ & $107.8^{\mathrm{a}}$ & 99.4 & $26.9^{\mathrm{c}}$ & 57.8 & $24.0^{\mathrm{c}}$ & 91.2 & 1.12 \\
\hline
\end{tabular}


The $\mathrm{N}$ content in kohlrabi (Table 5) was lower in leaves than in tubers and increased to $1.25-1.35 \% \mathrm{~N}$ at higher S doses. Higher S soil doses were reflected in an increase of leaf concentration from $0.50 \% \mathrm{~S}$ (Treatment $\mathrm{S}_{0}$ ) to $0.76 \% \mathrm{~S}$ (Treatment $\mathrm{S}_{2}$ ) while simultaneously the N/S ratio decreased from 2.42 to 1.77; see Table 5. S deficiency symptoms on the youngest leaves were only observed towards the end of the growing season - treatment $S_{0}$. Rosen et al. (2005) stated that the $\mathrm{N}$ dose has no effect on $\mathrm{S}$ concentration in cabbage tissues, which depended only on the applied dose of $110 \mathrm{~kg} \mathrm{ha}^{-1}$ of S. Sanderson \& Carter (2002) also discovered that the $\mathbf{S}$ content in brassica tissues increased after $\mathrm{S}$ fertilisation in the form of gypsum. Hlušek et al. (2003) detected that the $\mathrm{S}$ content increased in Chinese cabbage after $\mathrm{S}$ application to $0.89 \% \mathrm{~S}$ compared to $0.71 \% \mathrm{~S}$ in the control treatment without $\mathrm{S}$ fertilisation, and simultaneously a lower N/S ratio, decreasing from 4.84 to 3.40. Likewise Sanderson \& Ivany (1996)

Table 5. Chemical analyses of kohlrabi leaves $(\%$ in dry matter)

\begin{tabular}{cccc}
\hline Treatment & $\% \mathbf{N}$ & $\% \mathbf{S}$ & N/S \\
\hline $\mathrm{S}_{0}$ & 1.21 & 0.50 & 2.42 \\
$\mathrm{~S}_{1}$ & 1.25 & 0.58 & 2.15 \\
$\mathrm{~S}_{2}$ & 1.35 & 0.76 & 1.77 \\
\hline
\end{tabular}

observed that after the application of potassium sulphate and gypsum the $\mathrm{S}$ concentration in cabbage leaves increased to $0.70 \%$ and $1.45 \% \mathrm{~S}$ respectively.

The effect of $\mathrm{N}$ and $\mathrm{S}$ fertilisation on the spectrum of amino acids in kohlrabi tubers is presented in Table 6. shows that with the given level of $\mathrm{N}$ nutrition and increasing $\mathrm{S}$ level in the soil $\left(\mathrm{S}_{0}, \mathrm{~S}_{1}\right.$ and $\left.\mathrm{S}_{2}\right)$, the percentage sum $(\mathrm{g} / 16 \mathrm{~g} \mathrm{~N})$ of the content of sulphurous amino acids $\Sigma$ cysteine + methionine decreased by 16 $28 \%$ Table 6 . Cysteine $\left(\mathrm{S}_{0}: \mathrm{S}_{1}=\right.$ by $23 \% ; \mathrm{S}_{0}: \mathrm{S}_{2}=$ $26 \%$ ) and methionine deceased in the same order by 9 and $30 \%$, resp., and glycine also decreased by 6 $29 \%$. These results correspond to the findings of Smatanová et al. (2004) who also stated that the content of methionine in spinach decreased from 0.76 to $0.66 \mathrm{~g} \mathrm{~kg}^{-1}$ when the levels of $\mathrm{S}$ in the soil increased from 7.8 to $30.6 \mathrm{mg} \mathrm{kg}-1$ of $\mathrm{SO}_{4}-\mathrm{S}$, simultaneously reducing the cysteine content from 0.58 to $0.45 \mathrm{~g} \mathrm{~kg}^{-1}$ as a result of the increasing S level in the soil from 20.6 to 30.6 ppm. Lošák \& Ducsay (2005) also observed a statistically significant decrease in the methionine concentration in onion tubers by $6.8 \%$ at the highest level of $\mathrm{S}$ in the soil $\left(60 \mathrm{mg} \mathrm{kg}^{-1}\right.$ of $\mathrm{SO}_{4}-\mathrm{S}$ ). On the contrary, Eppendorfer \& Eggum (1995) reported that in plant tissue under $\mathrm{S}$ deficiency the cysteine concentrations $(\mathrm{g} / 16 \mathrm{~g} \mathrm{~N})$ declined more than methionine.

In other essential amino acids at different levels of $\mathrm{S}$ fertilisation virtually the same values of amino acids valine and tyrosine and of the non-essential amino acids aspartic acid and serine were observed. No substantial differences between treatments $\mathrm{S}_{0}$ and $\mathrm{S}_{1}$

Table 6. Percentage content of amino acids (AA) in kohlrabi tubers at fertilisation level $\mathrm{S}_{0}, \mathrm{~S}_{1}$ and $\mathrm{S}_{2}(\mathrm{~g} / 16 \mathrm{~g} \mathrm{~N})$

\begin{tabular}{|c|c|c|c|c|c|c|c|c|c|c|c|c|}
\hline \multirow[b]{2}{*}{ AA } & \multicolumn{3}{|c|}{$\mathbf{S}_{0}$} & \multicolumn{3}{|c|}{$\mathbf{S}_{1}$} & \multicolumn{3}{|c|}{$\mathbf{S}_{2}$} & \multicolumn{3}{|c|}{ Total $(n=12)$} \\
\hline & Mean & \pm & S.D. & Mean & \pm & S.D. & Mean & \pm & S.D. & Mean & \pm & S.D. \\
\hline Cysteine & 1.77 & \pm & 0.409 & 1.35 & \pm & 0.232 & 1.31 & \pm & 0.091 & 1.48 & \pm & 0.330 \\
\hline Methionine & 1.76 & \pm & 0.155 & 1.60 & \pm & 0.163 & 1.22 & \pm & 0.271 & 1.53 & \pm & 0.301 \\
\hline$\Sigma \mathrm{Cys}+\mathrm{Met}$ & 3.53 & \pm & 0.532 & 2.95 & \pm & 0.302 & 2.53 & \pm & 0.258 & 3.01 & \pm & 0.549 \\
\hline Threonine & 5.24 & \pm & 0.437 & 5.24 & \pm & 0.573 & 4.21 & \pm & 0.210 & 4.89 & \pm & 0.642 \\
\hline Valine & 6.56 & \pm & 0.186 & 6.37 & \pm & 0.231 & 6.06 & \pm & 0.377 & 6.33 & \pm & 0.330 \\
\hline Isoleucine & 4.16 & \pm & 0.301 & 4.17 & \pm & 0.168 & 3.65 & \pm & 0.258 & 3.99 & \pm & 0.340 \\
\hline Leucine & 8.20 & \pm & 1.274 & 8.50 & \pm & 0.256 & 5.90 & \pm & 0.203 & 7.53 & \pm & 1.396 \\
\hline Tyrosine & 4.01 & \pm & 0.258 & 3.90 & \pm & 0.493 & 3.97 & \pm & 0.456 & 3.96 & \pm & 0.379 \\
\hline Phenylalanine & 0.07 & \pm & 0.034 & 0.39 & \pm & 0.199 & 0.18 & \pm & 0.222 & 0.21 & \pm & 0.209 \\
\hline Histidine & 1.86 & \pm & 0.062 & 2.25 & \pm & 0.436 & 2.68 & \pm & 0.136 & 2.26 & \pm & 0.426 \\
\hline Lysine & 5.25 & \pm & 1.061 & 6.70 & \pm & 0.168 & 3.32 & \pm & 0.175 & 5.09 & \pm & 1.551 \\
\hline Arginine & 3.88 & \pm & 1.060 & 3.93 & \pm & 0.386 & 2.47 & \pm & 0.684 & 3.43 & \pm & 0.986 \\
\hline$\Sigma \mathrm{EAA}$ & 39.23 & \pm & 2.925 & 41.45 & \pm & 0.483 & 32.44 & \pm & 1.728 & 37.69 & \pm & 4.652 \\
\hline Aspartic acid & 10.82 & \pm & 1.523 & 9.70 & \pm & 0.222 & 9.38 & \pm & 0.584 & 9.97 & \pm & 1.074 \\
\hline Serine & 5.74 & \pm & 0.417 & 5.96 & \pm & 0.103 & 5.12 & \pm & 0.577 & 5.61 & \pm & 0.530 \\
\hline Glutamic acid & 11.85 & \pm & 0.584 & 10.85 & \pm & 0.974 & 28.33 & \pm & 1.621 & 17.01 & \pm & 8.432 \\
\hline Proline & 4.95 & \pm & 0.489 & 5.47 & \pm & 1.472 & 3.65 & \pm & 1.521 & 4.69 & \pm & 1.388 \\
\hline Glycine & 10.51 & \pm & 0.616 & 9.85 & \pm & 0.276 & 7.50 & \pm & 0.317 & 9.29 & \pm & 1.402 \\
\hline Alanine & 10.75 & \pm & 0.688 & 10.07 & \pm & 0.786 & 7.90 & \pm & 0.911 & 9.58 & \pm & 1.464 \\
\hline$\Sigma$ NEAA & 54.62 & \pm & 3.198 & 51.90 & \pm & 2.282 & 61.88 & \pm & 0.375 & 56.15 & \pm & 4.853 \\
\hline
\end{tabular}


were found in threonine, isoleucine, leucine, arginine, $\Sigma$ EAA and alanine, however between treatments $\mathrm{S}_{0}$, $S_{1}$ and $S_{2}$ the content dropped in a range of $37-9 \%$ in all cases. The content of amino acid lysine increased between treatments $\mathrm{S}_{0}$ and $\mathrm{S}_{1}$ by $28 \%$, that of proline by $10 \%$; on the contrary, from $\mathrm{S}_{0}$ to $\mathrm{S}_{2}$ lysine decreased by $37 \%$ and proline by $26 \%$, and between treatments $\mathrm{S}_{1}$ and $\mathrm{S}_{2}$ lysine dropped $50 \%$ and proline $33 \%$. The only essential amino acid content that increased with increasing $\mathrm{S}$ doses was histidine. The increase observed on $\mathrm{S}_{1}$ and $\mathrm{S}_{2}$ treatments as compared with $\mathrm{S}_{0}$ was $21 \%$ and $44 \%$, respectively; from $S_{1}$ to $S_{2}$ the in increase was $9 \%$. In treatment $\mathrm{S}_{2}$ the glutamic acid content increased extremely, by more than $150 \%$, compared to the $\mathrm{S}_{0}$ and $\mathrm{S}_{1}$ treatments. The high content of $\Sigma$ NEAA under treatment $\mathrm{S}_{2}$ was probably affected by the high concentration of glutamic acid. The phenylalanine concentrations ranged between 0.07 and $0.39 \%$. Eppendorfer \& Eggum (1994) also explored the effect of different levels of $\mathrm{N}, \mathrm{P}, \mathrm{K}$ and $\mathrm{S}$ on the amino acid content in potato tubers. They stated that increased $\mathrm{S}$ doses had a negative effect on cysteine, methionine, lysine and leucine concentrations, but raised the glutamic acid concentration.

\section{CONCLUSIONS}

The result of a one-year greenhouse pot experiment was that $\mathrm{S}$ fertilisation contributed to stabilise kohlrabi tuber yields of while simultaneously reducing $\mathrm{NO}_{3}$. contents both in the consumable parts and leaves considerably. The concentrations of amino acids, with exception of cysteine, methionine, $\Sigma$ cysteine + methionine and glycine, did not change. It would also be appropriate to apply S-containing mineral fertilisers in doses of 45-90 $\mathrm{kg} \mathrm{ha}^{-1}$ of $\mathrm{S}$ for kohlrabi cultivation.

\section{ACKNOWLEDGEMENTS}

This study was supported by the Research plan No. MSM6215648905 "Biological and technological aspects of sustainability of controlled ecosystems and their adaptability to climate change“, which is financed by the Ministry of Education, Youth and Sports of the Czech Republic.

\section{LITERATURE CITED}

EPPENDORFER, W.H. \& EGGUM, B.O. Dietary fiber, starch, amino-acids and nutritive-value of potatoes as affected by sulphur, nitrogen, phosphorus, potassium, calcium and water-stress. Acta Agric. Scand. Section B-Soil Plant Sci., 44:107-115, 1994
EPPENDORFER, W.H. \& EGGUM, B.O. Sulphur amino-acid content and nutritive-value of pea and cauliflower crude protein as influenced by sulphur deficiency. J. Plant Nutr. Soil Sci., 158:89-91, 1995.

FELLER, C. \& FINK, M. Nitrogen uptake of kohlrabi, estimated by growth stages and an empirical growth model. J. Plant Nutr. Soil Sci., 160:589-594, 1997.

HANEKLAUS, S.; HOPPE, L.; BAHADIR, M. \& SCHNUG, E. Sulphur nutrition and alliin concentrations in Allium species. In: CRAM, W.J.; DE KOK, L.J.; STULEN, I.; BRUNOLD, C. \& RENNENBERG, H., eds. Sulphur metabolism in higher plants. Molecular, ecophysiological and nutritional aspects. Leiden, Backhuys Publishers, 1997. 367p.

HLUŠEK, J.; RICHTER, R. \& RIGEROVÁ, L. Sulphur in the nutrition and fertilization of vegetables. Chemia Inzynieria Ekologiczna, 11:1383-1390, 2003.

HLUŠEK, J.; RICHTER, R. \& RYANT, P. Výživa a hnojení zahradních plodin. Praha, Zemědělec, 2002. 81p.

JANZEN, H.H. \& BETTANY, J.R. Sulphur nutrition of rapeseed: I. Influence of fertilizer nitrogen and sulfur rates. Soil Sci. Soc. Am. J., 48:100-107, 1984

KRÁĚMAR, S.; GAJDÚŠEK, S.; JELÍNEK, P.; ZEMAN, L.; KOZEL, V.; KOZLOVÁ, M. \& KRÁĚMAROVÁ, E. Changes in amino acid composition of goat's colostrum during the first 72 hours after birth. Czech J. Anim. Sci., 44:541-545, 1998

LOŠÁK, T. Response of onion (Allium cepa, L.) to nitrogen and sulphur fertilization. Veg. Crops Res. Bull., 63:67-75, 2005

LOŠÁK, T. \& DUCSAY, L. The effect of sulphur fertilisation on yields and quality of onion. Chemické Listy, 99:525528,2005

MARSCHNER, H. Mineral nutrition of higher plants. 2.ed. London, Academic Press, 1995. 889p.

MEHLICH, A. Mehlich-3 soil test extractant: A modification of Mehlich-2 extractant. Comm. Soil Sci. Plant Anal., 15:1409-1416, 1984.

MENGEL, K. \& KIRKBY, E.A. Principles of plant nutrition. 5.ed. Dodrecht, Kluwer Academic Publisher, 2001. 849p.

MINAŘÍK, B. \& HOFBAUER, J. Zaèíname s obsluhou, s analýzou dat v programu Unistat verze 5. Pøíruèka, 2003. $87 \mathrm{p}$.

Ministerstvo Zemědělství Ěeské Republiky.. Postupy laboratorního zkoušení krmiv, doplňkových látek a premixù I. 2001. 266p.

OFFICIAL JOURNAL L 206. COMMISSION DIRECTIVE, 8., 78/633/EEC, 1978 Establishing Community methods of analysis for the official control of feeding stuffs. 1978 . p.43-55.

PAULSEN, H.M. Sulphur Day, 10.11.2001, FAL Braunschweig. Access under: <http:// www.pb.fal.de> 
PRÁŠKOVÁ, L. Harmonious nutrition by nitrogen and sulphur and its relation to the yield and quality of selected vegetables. Brno, Mendel University of Agriculture and Forestry in Brno, 2006. 164p. (Tese de Mestrado)

RICHTER, R.; HLUŠEK, J. \& HŘIVNA, L. Výživa a hnojení rostlin - Praktická cvičení, Brno, Mendelova Zemědělská a Lesnická Univerzita v Brnì, 1999. 188p.

ROSEN, C.J.; FRITZ, V.A.; GARDNER, G.M.; HECHT, S.S.; CARMELLA, S.G. \& KENNEY, P.M. Cabbage yield and glucosinolate concentrations as affected by nitrogen and sulphur fertility. Hortscience, 40:1493-1498, 2005

SANDERSON, K.R. \& CARTER, M.R. Effect of gypsum and elemental sulphur on calcium and sulphur content of rutabagas in Podzolic soils. Can. J. Plant Sci., 82:785-788, 2002.

SANDERSON, K.R. \& IVANY, J.A. Supplemental soil sulphur increases cabbage yield. Can. J. Plant Sci., 76:857-859, 1996.

SCHENK, M.; HEINS, B. \& STEINGROBE, B. The significance of root development of spinach and kohlrabi for N-fertlilization. Plant Soil, 135:197-203, 1991.

SCHNUG, E. Sulphur nutrition and quality of vegetables. Sulphur Agric., 14:3-7, 1990.

SCHNUG, E. Sulphur nutritional status of European Crops and consequences for agriculture. Sulphur Agric., 15:7$12,1991$.
SCHUBERT, A. Pflanzenernährung - Vorlesungen. Giessen, Justus-Liebig-Universität, 2002.

SCHUPHAN,W. Mensch und Nahrungspflanze. Den Haag, Junk Publ., 1976. 122p.

SHAROF, H.C. \& WIER, U. Calculation of nitrogen immobilization and fixation. Gartenbau Hannover Germany, 157:11-16, 1994.

SMATANOVÁ, M.; RICHTER, R. \& HLUŠEK, J. Spinach and red pepper response to nitrogen and sulphur fertilization. Plant Soil Environ., 50:303-308, 2004.

SNEDECOR, G.W. \& COCHRAN, W.G. Statistical methods. 6.ed. Ames, Iowa State University Press, 1967. 579p.

STEINGROBE, G. \& SCHENK, M.K. Influence of nitrate concentration at the root surface on yield and nitrate uptake of kohlrabi (Brassica oleracea - gongyloides, L.) and spinach (Spinacia oleracea, L.). Plant Soil, 135:205211, 1991.

VANĚK, V.; KOLÁř, L.; ŠTÍPEK, K. \& JAKL, M. The metabolism of sulphur in plants and the role of S compounds. In: INTERNATIONAL CONFERENCE REASONABLE USE OF FERTILIZERS, 7., Praha, 2001. Proceedings... Praha, ÈZU, 2001. p.27-34.

VETTER, H. Landwirtschaftliche Produktion, Nahrungsqualität und Umwelt. VDLUFA-Schriftenreihe, 28:19-37,1988. 